\title{
Dietary protein and carbohydrate affect feeding behavior and metabolic regulation in hummingbirds (Melanotrochilus fuscus)
}

\author{
Las proteínas y carbohidratos dietarios afectan la conducta de alimentación \\ y la regulación metabólica en picaflores (Melanotrochilus fuscus)
}

FLAVIA P. ZANOTTO ${ }^{1 *} \&$ J.E.P.W. BICUDO

\author{
Department of Physiology, Biosciences Institute, University of São Paulo, \\ 05508-900, São Paulo, Brazil \\ ${ }^{1}$ Current address: Universidade Presbiteriana Mackenzie, FCBEE, \\ Rua da Consolação 930, 01302-907, São Paulo, Brazil \\ *E-mail for corresponding author: fzanotto@usp.br
}

\begin{abstract}
The objective of this work was to link hummingbird feeding behavior with metabolic regulation and in addition to assess whether dietary composition would affect entrance into torpor. Hummingbirds were fed a combination of diets with contrasting amounts of protein and carbohydrate. The diets were composed of the following: $2.4 \%$ protein $(\mathrm{P})-12 \%$ sucrose $(\mathrm{S})$ and $0.8 \%$ protein $(\mathrm{P})-36 \%$ sucrose $(\mathrm{S})$. The main findings showed that periods of feeding on each of the diets could be distinguished as separate bouts or feeding events. Hummingbirds presented to high protein-low carbohydrate diets (2.4P-12S) ingested a larger volume of diet, fed for longer (both around 1.7x) and increased the interval between feedings compared with hummingbirds fed diets $0.8 \mathrm{P}$ 36S. Physiological regulation between feeding events, on the other hand, was achieved through an increase in metabolic rate for low protein-high sugar diets $(0.8 \mathrm{P}-36 \mathrm{~S})$. This response could probably be related to high sucrose assimilation rates through the digestive system of hummingbirds, a process already known to be very efficient in these birds. Additionally, there was a steeper decrease in oxygen consumption for hummingbirds fed diets 2.4P-12S during fasting and a suggestion of a higher torpor incidence in birds fed these diets.
\end{abstract}

Key words: hummingbird feeding, carbohydrate and protein interaction, unbalanced diet, feeding behavior, torpor.

\section{RESUMEN}

El objetivo de este trabajo fue unir la conducta de alimentación de picaflores con su regulación metabólica y además determinar cómo la composición dietaria podría afectar la entrada en sopor. Los picaflores fueron alimentados con una combinación de dietas con cantidades contrastantes de proteínas y carbohidratos. La composición dietaria fue: $2,4 \%$ proteína $(\mathrm{P})-12 \%$ sacarosa $(\mathrm{S})$ y $0.8 \%$ proteína $(\mathrm{P})$ - $36 \%$ (sacarosa) (S). Se observó que para cada dieta, los períodos de alimentación se pueden distinguir como eventos separados de alimentación. Cuando se enfrentan a dietas de alta proteína-bajo carbohidratos (2,4P-12S), los picaflores ingieren grandes volúmenes de alimento, se alimentan por mayor tiempo (cerca de 1,7x) y aumentan el intervalo entre alimentación en comparación a los picaflores enfrentados a dietas $0,8 \mathrm{P}-36 \mathrm{~S}$. Por otra parte, la regulación fisiológica entre eventos de alimentación, se logró con un aumento en la tasa metabólica para las dietas de baja proteína-alta azúcar $(0,8 \mathrm{P}-36 \mathrm{~S})$. Esta respuesta podría esta relacionada con una alta asimilación de sacarosa, un proceso conocido en picaflores. Además, existió un fuerte decremento en consumo de oxígeno en picaflores alimentados con 2,4P-12S durante ayuno, sugiriendo una alta incidencia de sopor.

Palabras clave: alimentación en picaflores, interacción carbohidrato-proteína, dieta desbalanceada, conducta de alimentación, sopor.

\section{INTRODUCTION}

Vertebrates usually ingest a mixed diet and the basis for this selection is poorly understood (see recent work by Hailey et al. 1998). Hummingbirds, on the other hand, feed on a very specialized diet, nectar. Although they usually feed on a variety of flowers, and the composition of nectar varies with location and altitude, the main components in nectar are still very similar (Stiles 1976, Snow \& Snow 1986). Even as diet-specialists, however, they need to 
have access to proteins and aminoacids for growth of muscles and tissues. In this point of view, hummingbirds represent an interesting model system to study physiological performance in conjunction with food quality in terms of main dietary components such as protein and carbohydrates, this last one known to be very abundant in nectar.

Hummingbirds are known to possess extreme regulatory mechanisms related to an array of physiological parameters which are associated with energy regulation. They have high sucrose assimilation rates through the digestive system (Diamond et al. 1986) and the highest mass-specific metabolic rates among vertebrates, achieved during hovering flight, in addition to a number of other extremely effective physiological strategies related to respiration and metabolic capacity (Suarez et al. 1986, 1988, 1991, Johansen et al. 1987, Suarez \& Moyes 1992). In relation to feeding strategies, nutritional and digestive aspects of hummingbird dietary selection have been studied in these birds (Stiles 1976, Hainsworth \& Wolf 1976, Wolf \& Hainsworth 1977, Martínez del Río 1990), together with sugar absorption and transport rates (Diamond et al. 1986, Karasov et al. 1986, Martínez del Río et al. 1992) as well as aspects of foraging behavior optimality criteria related to parameters such as meal size and volume (DeBenedictis et al. 1978, Kingsolver \& Daniel 1983, Houston 1993, Roberts 1996). Moreover, there is a large number of investigations on nectar composition of flowers visited by hummingbirds (Baker \& Baker 1973, Baker 1975, Hainsworth \& Wolf 1976, Hiebert \& Calder 1983, Gottsberger et al. 1984).

Usually hummingbirds prefer sucrose over other sugars sources (Martínez del Río 1990), and sugar nectar concentration in plants can vary from 7-67\% (see references in Beuchat et al. 1990). Due to the large importance of sugar for these birds, few investigations have dealt with protein requirements (for exceptions see: Hainsworth \& Wolf 1976, Brice \& Grau 1991, Brice 1992, López-Calleja et al. 2003). In general, hummingbirds require low levels of protein compared to other birds, around $1.5 \%$ daily on a dry weight basis (Brice \& Grau 1991). Protein is generally supplied by arthropod feeding. Amino acids are found in nectar in very low amounts and its importance as a protein source is unknown (Baker \& Baker 1973). Furthermore, no work has dealt with both protein and carbohydrate added together in purified diets. This kind of scenario is conceivable for these birds in nature, because hummingbirds are subjected to a dichotomy in relation to the acquisition of these nutrients when they feed alternatively on insects and nectar sources, which contain widely different amounts of proteins and carbohydrates in each one.

Interestingly, feeding metabolic rates uncoupled from hovering flight have not been studied in hummingbirds, apart from a report by Suarez et al. (1990), when they were fed on a sugar diet. This behavior could represent an energy-saving strategy for these birds, because they apparently show this behavior in nature whenever possible (Wells 1993) and, additionally, this strategy seems to be linked to energy gain (Hainsworth \& Wolf 1983, Dreisig 1997). The thermogenic effect of diets where both protein and carbohydrate are added together represents a novel and unexplored subject for study in these birds. Therefore, the aim of this work was twofold: first, to contrast the feeding behavior of hummingbirds fed diets with contrasting amounts of both protein and carbohydrate, and secondly, to test whether there was a difference in the thermogenic effect between the two diets. Additionally, given their known metabolic flexibility together with a specialized food niche, hummingbirds are potentially interesting model systems to study food intake.

\section{MATERIAL AND METHODS}

\section{Animals}

The experimental work was carried out from July to November 1997 at University of São Paulo. Fifteen hummingbirds (Melanotrochilus fuscus) of both sexes were captured at a resort hotel in Monte Verde (State of Minas Gerais, MG, Brazil) using mist nets. Mean \pm SE body mass was $7.23 \pm 0.18 \mathrm{~g}$. Animals were housed in indoor flight cages $\left(12 \mathrm{~m}^{2}\right)$ for no longer than a month. They were kept under a controlled photoperiod (12:12LD) and ambient temperature varied from around a mean low of $20{ }^{\circ} \mathrm{C}$ to a mean high of $28{ }^{\circ} \mathrm{C}$. They were allowed to 
acclimate for at least a week before experimental work started (Brice \& Grau 1991). Two birds were kept in each cage. Competition for feeders was very low because food was available in large amounts and two feeders were accessible during the whole acclimation period. Usually these birds reproduce from November onwards, discarding confounding effects over reproductive differences between animals.

\section{Diets}

The birds were fed ad libitum during the maintenance period. The liquid purified diet contained a mixture of aminoacids at $0.5 \%$ (Glicopan P). To this aminoacid premix it was added corn oil (3\%), a vitamin supplement (0.05 $\%$-Vita Gold), $1 \%$ calcium carbonate (Brice \& Grau 1991) and sucrose $20 \%$ (see Table 1 for detailed diet composition). Because of unknown effects of the palatability of the above diet, birds also had access to a diet containing sucrose $20 \%$ offered alone. The diets were prepared in mineral water (Table 1). The birds also had access to Drosophila three times a week.

\section{TABLE 1}

Maintenance diet for hummingbirds

(Melanotrochilus fuscus) in captivity

Dieta de mantención en cautividad para picaflores (Melanotrochilus fuscus)

\begin{tabular}{lc}
\hline Ingredients & Diet composition (\%) \\
\hline Sucrose & 20 \\
Aminoacid mixture & 0.5 \\
Corn oil & 3 \\
Vitamins $^{2}$ & 0.03 \\
$\mathrm{CaCO}_{3}$ & 1 \\
\hline
\end{tabular}

1 Glicopan P - composed of the following aminoacids $\left(\mathrm{mg} . \mathrm{kg}^{-1}\right)$ : lysine 2,820; methionine 426; arginine 2,364; aspartic acid 3,180; threonine 421; serine 480; glutamic acid 5,268; proline 8,340 ; glycine 13,260 ; hydroxiproline 4,956; alanine 5,896; cysteine 216 ; valine 1,314 ; isoleucine 570; leucine 1,620; tyrosine 180; phenylalanine 936; tryptophan 156.

2 Vita Gold - composed of the following vitamins (100 ml): vit. A 15,000,000 UI; vit D3 4,000,000 UI; vit. E $1,000 \mathrm{UI}$; vit. B1 4,000 mg; vit. B2 $1,500 \mathrm{mg}$; vit. B6 $2,000 \mathrm{mg}$; vit. B12 4,800 $\mu \mathrm{g}$; nicotinamide $10,000 \mathrm{mg}$. The liquid diet was dissolved in mineral water which contained the following minerals (mg. $1^{-1}$ ): $\mathrm{NaCl} 11.23$; $\mathrm{MgCO} 38.68$ CaCO3 6.79; KNO3 3.67; $\mathrm{MgNO} 3$ 2.01; NaNO3 0.78; $\mathrm{BaCO} 3$ 0.09; The birds also had access to $20 \%$ sucrose offered alone.
Experimental protocol for measuring feeding behavior and metabolic rate during feeding

Each bird was used once and pre-treated for 48 h. During the pre-treatment period each bird was fed a combination of one of two experimental diets. The experimental diets were: (1) $0.8 \%$ protein (P) (peptone as enzymatic hydrolysate) and $36 \%$ sucrose (S) (2) $2.4 \%$ protein $(\mathrm{P}), 12 \%$ sucrose $(\mathrm{S})$. The experimental diets were based on a concentration range of sucrose normally found in flower nectar in the southeast of Brazil (Snow \& Snow 1986) and the protein was chosen based on amounts usually needed by these birds (Brice \& Grau 1991). The diets were chosen aiming to test how the birds regulate both macronutrients on a behavioral and metabolic basis when presented together on widely differing concentrations (a 3 times difference in the amounts of protein and carbohydrate between diets). The caloric content was $2.6 \mathrm{x}$ higher for diet $0.8 \mathrm{P}-36 \mathrm{~S}$ compared with diets $2.4 \mathrm{P}-12 \mathrm{~S}$. The diets also contained vitamins (Glicopan P - $0.05 \%$ ). Corn oil and calcium carbonate were not added to the experimental diets due to the short period of pre-treatment (see below) and to avoid any interactions between the protein and carbohydrate content of the diet with these other components. The birds also had access to mineral water during this experimental period (see Table 1 for its mineral content).

During the pre-treatment period as outlined above, birds were removed from the holding cages and put in a smaller cloth cage (104 x 95 $\mathrm{x} 68 \mathrm{~cm}$ ) and exposed to one of the experimental diets. Only one bird was used per day. Minutes before lights went off the day before the metabolic rate measurements were performed, a bird had its diet withdrawn to increase the probability that the bird ate the diet during the next experimental day and to homogenize the animals in relation to their feeding status. In the morning of next day (approximately $1 \mathrm{~h}$ after lights on), the bird was weighed and put inside the respirometer box (total volume of $1509 \mathrm{ml}$ ), which contained a perch and a $5 \mathrm{~mL}$ syringe inserted into the side of the box through a rubber hole. The syringe was filled with one of the experimental diets and had at its end a plastic red flower. The respirometer box was surrounded by card boxes 
to avoid disturbance. The bird would take less than $10 \mathrm{~min}$ to settle down and perch in the respirometer box. A time lapse recorder (SV9000TX - Samsung) attached to a video monitor was directed to the respirometer box and the bird's feeding behavior was monitored for the entire measurement of metabolic rate. It was possible to separate behavioral events within $2 \mathrm{~s}$. At the end of a $1.5 \mathrm{~h}$ recording, the amount of liquid diet eaten during the whole period was recorded and the bird was reweighed and returned to the cloth cage. All birds were perching during the whole experimental period of metabolic rate measurement.

The feeding parameters measured during the behavioral observations were the following: bout criterion: the minimum gap length considered to be between rather than within meals; gap: any period of time separating periods of feeding, i.e. including gaps both within and between meals; meal time: time spent in a meal, including non-feeding periods (shorter than the bout criterion) within a meal; intermeal interval: time interval (longer than the bout criterion) between meals; intra-meal pause: a non-feeding period within a meal (shorter than the bout criterion); latency: time spent until first feeding starts.

Experimental protocol for measuring metabolic rate during non-feeding stage

After the end of the above feeding stage $(2.5 \mathrm{~h}$ after lights on), the bird was returned to the cloth cage and kept with the same experimental diet for another $3 \mathrm{~h}$ ( $5.5 \mathrm{~h}$ after lights on). The experimental diet was then removed $2 \mathrm{~h}$ before next experimental run to homogenize the birds feeding status. Next, the bird was weighed and placed into another respirometry box $(7.5 \mathrm{~h}$ after lights on). The box (110 mL internal volume) was a tube made of PVC and the bird was placed sideways to see whether there was any dietary effect on metabolic rate on a nonfeeding bird and whether the bird would go into torpor. This experimental run lasted $2 \mathrm{~h}$. The bird also had a thermocouple (TT-T-40, Omega Engineering Inc.) connected to its thorax and secured by a tape to the skin underneath the feathers, to ensure thermal isolation with the environment. The thermocouple was linked to a software (Elipse Windows, Elipse Software
Ltd. 1997), which registered the bird external body temperature every second for $2 \mathrm{~h}$. The first $10 \mathrm{~min}$ of data collected after the bird was inserted in the respirometer box was discarded. The smaller respirometry box was used in this experimental run to allow detection of $\mathrm{VO}_{2}$ if birds enter torpor (which usually goes down sharply), and to ensure that the thermocouple would stay in place.

\section{Respirometry}

Carbon dioxide production and $\mathrm{O}_{2}$ consumption were measured continuously using a flow-through respirometer, and data acquisition was made possible by means of a computerized system (Sable System Respirometer, Salt Lake City, Utah, USA). Air temperature was $21 \pm 1{ }^{\circ} \mathrm{C}$ throughout the observation period. Air flow through the respirometer was regulated by a mass flow controller (F1-1495-G, Omega Engineering Inc.) at $336 \mathrm{~mL} \mathrm{~min}{ }^{-1}$ for the protocol measuring metabolic rate during feeding and at $267 \mathrm{~mL} \mathrm{~min}-1$ for the measurement of metabolic rate during non-feeding stage. The flow meter was downstream of the experimental chamber and the $\mathrm{O}_{2}$ analyzer. The air leaving the respirometer box was dried (Drierite column) before being directed to the $\mathrm{CO}_{2}$ analyzer (AMETEK CD-3A) and the $\mathrm{O}_{2}$ analyzer (AMETEK S-3A/I), each in a different channel. Data were baseline corrected, assuming that the readings followed a linear drift with time. Time lag correction between $\mathrm{CO}_{2}$ an $\mathrm{O}_{2}$ readings were performed. Data for metabolic rate during feeding were Ztransformed using Sable Systems Software to get instantaneous values of gas exchange according to Bartholomew et al. (1981).

The rate of oxygen consumption was calculated according to equation $3 \mathrm{~b}$ of Withers (1977). Data were transformed to $\mathrm{mL} \mathrm{g}^{-1} \mathrm{~h}^{-1}$ after calculations.

\section{Statistical analysis}

All variables were tested for normality in the distribution (Kolmogorov-Smirnov test) and for homogeneity of variances (Levene's test) before analysis.

Log survivor curves were derived from the behavioral observations and the relationship 
between gap frequency and gap length was analyzed by checking for the highest significant correlation coefficient starting from the first $3 \mathrm{~s}$ of feeding events and comparing to the next seconds, until finding the inflection point where the frequency of feeding declined. When the highest significant correlation coefficient was found, the determined inflection point was checked for a non-significant linear regression for the next seconds to further confirm the absence of a downward trend in the data. Behavioral parameters derived from the log survivor curves (see Table 2) were analyzed through one-way ANOVA using diets as a factor. Oxygen consumption during feeding and non-feeding stage was compared through a non parametric test, due to unequal sample size and to violation of analysis of variance assumptions. Therefore, the feeding or nonfeeding values were compared between diets for each time period through Kruskal-Wallis test. Differences within a diet for different time periods were compared through Friedman's ANOVA test for related samples (Sokal \& Rohlf 1981). This statistical test was chosen because the same group of individuals was tested repeatedly over a period of time. Mean total $\mathrm{VO}_{2}$ during non-feeding stage was also analyzed through a one-way ANOVA, using diet as a factor.

Individual oxygen consumption over a 10 min period was plotted against skin temperature within the same time period for all birds fed each diet and tested for any significant correlation between these two variables. Statistical significance was accepted at $\mathrm{P}<0.05$ throughout.

\section{RESULTS}

\section{Behavior}

Defining a meal: survivor curves were plotted for frequency of gaps between periods of feeding (Fig. 1). The curves for both diets show an initial steep downward slope, followed by a shallower gradient. This trend indicates that feeding occurs in bouts (meals) and the point at which the slope changes distinguishes intrameal pauses from intermeal gaps or pauses (see Simpson 1982). For hummingbirds fed diet $0.8 \mathrm{P}$ (protein) - 36S (sucrose), the inflection point distinguishing intra-meal pause from intermeal interval was at $6 \mathrm{~s}\left(\mathrm{r}^{2}=0.55, \mathrm{P}<\right.$ 0.001 ) and for birds fed diet containing 2.4P$12 \mathrm{~S}$, the inflection point was at $8 \mathrm{~s}\left(\mathrm{r}^{2}=0.34, \mathrm{P}\right.$ $<0.001)$. After the inflection point for both diets was found, there was no significant regression relationship between gap frequency and time for the next $12 \mathrm{~s}\left(\mathrm{r}^{2}=0.02, \mathrm{P}=0.40\right.$ for $0.8 \mathrm{P}-36 \mathrm{~S} ; \mathrm{r}^{2}=0.00, \mathrm{P}=0.90$ for $2.4 \mathrm{P}-12 \mathrm{~S}$ ), confirming the non-existence of a downward trend in the data (Fig. 2). The results show that hummingbirds fed the combination of high protein; low carbohydrate diet ate for 2 more sec compared to hummingbirds fed a high carbohydrate, low protein diet.

TABLE 2

Summary of behavioral parameters, amount ingested and weight gain for hummingbirds fed two different diets during $1.5 \mathrm{~h}$ observation period. Diets were $0.8 \%$ protein, $36 \%$ sucrose and $2.4 \%$ protein, $12 \%$ sucrose Means \pm SE are shown. Means were compared through one-way ANOVA using diet as a factor. Significance levels and sample size (n) are shown

Resumen de los parámetros conductuales, cantidad de ingesta y ganancia de peso en picaflores alimentados con dos dietas diferentes durante un períodos de observación de $1,5 \mathrm{~h}$. Las dietas fueron $0,8 \%$ proteína, $36 \%$ sacarosa y $2,4 \%$ proteína $12 \%$ sacarosa. Se muestran las medias \pm SE. Los valores medios se compraron con una ANOVA de una vía usando dieta como factor. Se indica el nivel de significancia estadística y el número de réplicas (n)

\begin{tabular}{ccccccccc}
\hline Diet & $\mathrm{n}$ & $\begin{array}{c}\text { Amount } \\
\text { ingested(mL) }\end{array}$ & $\begin{array}{c}\text { Meal } \\
\text { time(s) }\end{array}$ & $\begin{array}{c}\text { Intermeal } \\
\text { interval(s) }\end{array}$ & $\begin{array}{c}\text { Number } \\
\text { of meals }\end{array}$ & $\begin{array}{c}\text { Latency } \\
(\mathrm{s})\end{array}$ & $\begin{array}{c}\text { Intra-meal } \\
\text { pause }(\mathrm{s})\end{array}$ & $\begin{array}{c}\text { Weight } \\
\text { gain }(\mathrm{g})\end{array}$ \\
\hline $0.8 \mathrm{P}-36 \mathrm{~S}$ & 6 & $1.25 \pm 0.16$ & $4.7 \pm 0.6$ & $115.0 \pm 35.6$ & $17.5 \pm 2.0$ & $766 \pm 227$ & $4.0 \pm 0.4$ & $0.58 \pm 0.14$ \\
$2.4 \mathrm{P}-12 \mathrm{~S}$ & 7 & $2.10 \pm 0.16^{* *}$ & $7.9 \pm 1.2^{*}$ & $232.9 \pm 38.1 *$ & $15.1 \pm 2.8$ & $1531 \pm 665$ & $4.8 \pm 0.6$ & $0.35 \pm 0.08$ \\
\hline
\end{tabular}

$* * \mathrm{P}<0.01, * \mathrm{P}<0.05$ 


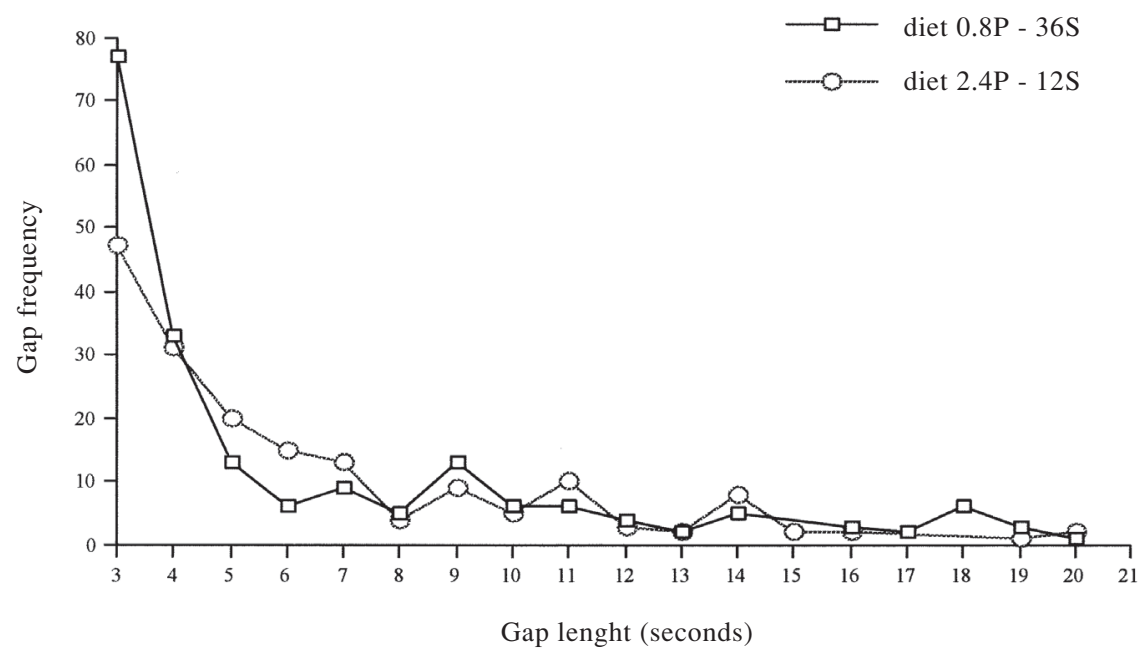

Fig 1: Survivorship curves for the distribution of gaps between periods of feeding. Each curve represents the pooled gaps for all hummingbirds fed each one of the diets. Diets were composed of $0.8 \%$ protein $(\mathrm{P}), 36 \%$ sucrose $(\mathrm{S})$ and $2.4 \%$ protein $(\mathrm{P}), 12 \%$ sucrose $(\mathrm{S})$. Number of replicates are $\mathrm{n}=6$ for diet $0.8 \mathrm{P}-36 \mathrm{~S}$, and $\mathrm{n}=7$ for $\operatorname{diet} 2.4 \mathrm{P}-12 \mathrm{~S}$.

Curvas de sobrevivencia para la distribución de interrupciones entre períodos de alimentación (segundos). Cada curva representa las interrupciones agregadas para todos los picaflores alimentándose de cada dieta. La composición dietaria fue: $0,8 \%$ proteína $(\mathrm{P}), 36 \%$ sacarosa $(\mathrm{S})$ y $2,4 \%$ proteína $(\mathrm{P}), 12 \%$ sacarosa $(\mathrm{S})$. El número de réplicas por tratamiento fue $\mathrm{n}$ $=6$ para la dieta $0,8 \mathrm{P}-36 \mathrm{~S}$ y $\mathrm{n}=7$ para la dieta $2,4 \mathrm{P}-12 \mathrm{~S}$.

diet $0.8 \mathrm{P}-36 \mathrm{~S}$

diet $2.4 \mathrm{P}-12 \mathrm{~S}$

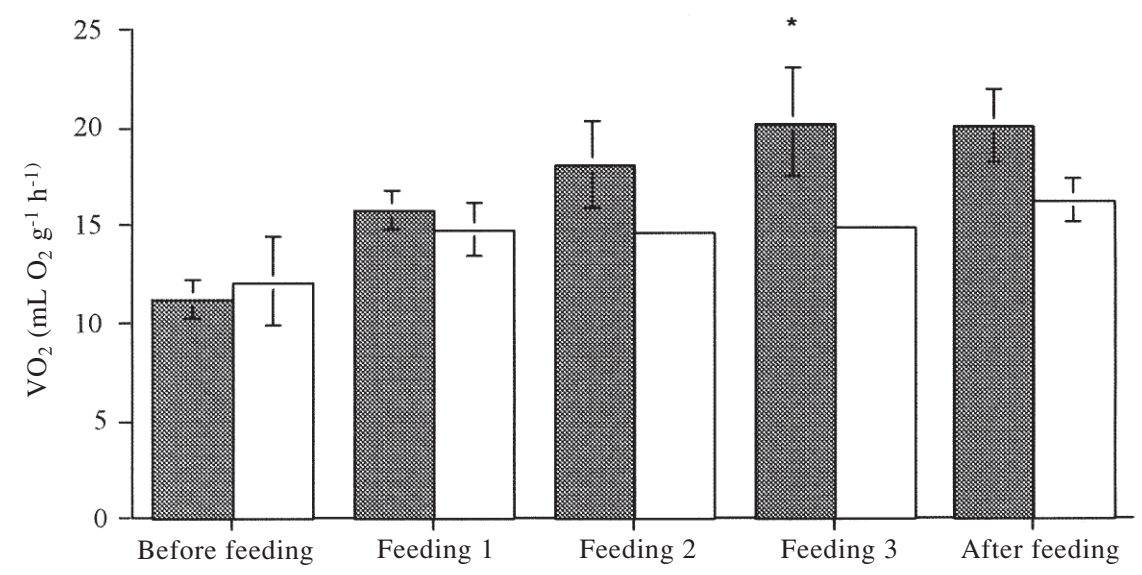

Fig. 2: Relationship between mean $\mathrm{VO}_{2}$ metabolic rate and three feeding events for hummingbirds fed two different diets. Feeding 1 refers to the first feeding event until a feeding interval longer than the intermeal interval for that diet was found. Feeding 2 and feeding 3 refers to the second and third feeding event in the same conditions as feeding 1 and after feeding refers to mean values of the variable taken for $5 \mathrm{~min}$ right at the end of the last feeding event. Separation of feeding events was based on behavioral data collected on the same hummingbirds. Diets as in Fig. 1. Means \pm SE are shown. Asterisks denote significant differences between diets (feeding 3, Kruskal-Wallis test, $\mathrm{P}<0.05$ ).

Relación entre $\mathrm{VO}_{2}$ tasa metabólica media y tres eventos de alimentación para picaflores alimentándose de dos dietas diferentes. Feeding 1 se refiere al primer evento de alimentación hasta un evento mayor que el evento interalimentación. Feeding 2 y feeding 3 se refieren al segundo y tercer evento de alimentación en la misma condición que feeding 1, y after feeding se refiere al valor medio de la variable tomada por $5 \mathrm{~min}$ al final del evento de alimentación. La separación de los eventos de alimentación se basó en datos conductuales recolectados en el mismo picaflor. Dietas como en la Fig. 1. Medias \pm SE. Los asteriscos indican diferencias significativas entre dietas (feeding 3, prueba de Kruskal-Wallis, $\mathrm{P}<0,05$ ). 
Table 2 shows various feeding parameters recorded from hummingbirds fed ad libitum the two different diets. Hummingbirds fed diet 2.4P$12 \mathrm{~S}$ ingested 1.7 times more liquid diet over a $1.5 \mathrm{~h}$ period compared to hummingbirds fed diet $0.8 \mathrm{P}-36 \mathrm{~S}$ (One-way ANOVA, $\mathrm{P}<0.01$ ). Meal time was similarly close to 1.7 times longer for hummingbirds fed diet 2.4P-12S compared to the other diet (One-way ANOVA, $\mathrm{P}<0.05$ ). The time interval between meals (intermeal interval) was twice as long for hummingbirds fed high protein, low carbohydrate diet compared to the other diet (One-way ANOVA, $\mathrm{P}<0.05$ ). There was no difference between diets, however, for number of meals, latency to start feeding and intra-meal pause (One-way ANOVA, $\mathrm{P}>0.05$ ). Weight gain for both diets also did not show any significant difference over $1.5 \mathrm{~h}$ period of recording.

Hummingbirds ingested around half the quantity of carbohydrate over $1.5 \mathrm{~h}$ on diets $2.4 \mathrm{P}-12 \mathrm{~S}$ compared to the low protein, high sugar diet (Table 3 ). In contrast, $5 \mathrm{x}$ less protein was ingested on diet $0.8 \mathrm{P}-36 \mathrm{~S}$ compared to the other diet. Similarly, birds ingested $35 \%$ more energy when fed diet $0.8 \mathrm{P}-36 \mathrm{~S}$ in relation to the other diet (Table 3 ).

\section{Metabolic rate during feeding stage}

Feeding events were separated according to intermeal interval data collected during the behavioral observations (see feeding behavior above). For example, feeding event 1 consisted of averaged values of instantaneous $\mathrm{VO}_{2}$ during a particular feeding period until a feeding interval longer than the intermeal interval for that diet was found. In this way some feeding events were clumped together and consisted of periods longer than individuals meal times reported in Table 2. Because the respirometer chamber was relatively large for the flux rate used in this work, this methodology would avoid feeding periods too short for an accurate measurement of $\mathrm{VO}_{2}$. At the same time, the traces have shown that feeding metabolic rate did not go down between short feeding periods, allowing some data clumping between feeding events and improving the $\mathrm{VO}_{2}$ measurements due to the washout time of the experimental chamber. A period of 5 min before any feeding event occurred and $5 \mathrm{~min}$ after the end of all feeding events was also quantified. This time was chosen because the birds would start feeding within this period when placed in the respirometer box. Some of the birds had up to seven feeding events clumped together. However, just the first three feeding events were considered, due to the few number of birds which had more feedings, precluding any statistical analyses.

The results showed that there was a significant effect of diet on $\mathrm{VO}_{2}$ consumption. Hummingbirds fed diet $0.8 \mathrm{P}-36 \mathrm{~S}$, consumed 1.4 times more oxygen on their third feeding (Kruskal-Wallis test, $\mathrm{P}<0.05$ ) compared with hummingbirds fed diet 2.4P-12S (Fig. 2). This difference, however, was not seen 5 min after feeding had finished. There was, similarly, a significant time effect for hummingbirds fed diet

\section{TABLE 3}

Amounts of protein and carbohydrate ingested and energy consumed for hummingbirds fed each one of the diets. Data for protein and carbohydrate eaten and energy ingested was calculated based on volume ingested on each diet (see Table 2). Columns 5 and 6 show how much carbohydrate and protein each bird would have eaten if volume ingested was the same for both diets

Cantidad de proteínas y carbohidratos ingeridos y energía consumida por los picaflores para cada dieta. Los datos de las proteínas y los carbohidratos consumidos y la energía ingerida se calcularon sobre la base del volumen ingerido (Tabla 2). Las columnas 5 y 6 (en itálicas) indican cuántas proteínas y carbohidratos debiese consumir cada ave si el volumen ingerido fuera el mismo en ambas dietas

\begin{tabular}{cccccc}
\hline Diet & $\begin{array}{c}\text { Carbohydrate } \\
\text { ingested }(\mathrm{g})\end{array}$ & $\begin{array}{c}\text { Protein } \\
\text { ingested }(\mathrm{g})\end{array}$ & kcal g-1 eaten $^{1}$ & $\begin{array}{c}\text { Carbohydrate }^{2} \\
\text { ingested }(\mathrm{g})\end{array}$ & $\begin{array}{c}\text { Protein }^{2} \\
\text { ingested }(\mathrm{g})\end{array}$ \\
\hline $0.8 \mathrm{P}-36 \mathrm{~S}$ & 0.45 & 0.01 & 1.93 & 0.45 & 0.01 \\
$2.4 \mathrm{P}-12 \mathrm{~S}$ & 0.25 & 0.05 & 1.26 & 0.15 & 0.03 \\
\hline
\end{tabular}

\footnotetext{
${ }^{1}$ Source: Schmidt-Nielsen (1990);

2 constant volume calculated was $1.25 \mathrm{~mL}$ (same amount eaten under diet $0.8 \mathrm{P}-36 \mathrm{~S}$ )
} 
0.8P-36S, showing an increase in $\mathrm{VO}_{2}$ consumption as feeding progressed (Friedman's ANOVA test, $\mathrm{P}<0.01$ ), unlike what was seen for hummingbirds fed diets 2.4P-12S, where values of $\mathrm{VO}_{2}$ consumption remained the same throughout (Friedman's ANOVA test, $\mathrm{P}=0.47$ ).

\section{Metabolic rate during non-feeding stage}

Oxygen consumption over a 2-h period for both diets is shown in Fig. 3. For birds fed diets $2.4 \mathrm{P}-12 \mathrm{~S}$, there was a larger decrease in $\mathrm{VO}_{2}$ consumption with time as compared to the decrease seen for birds fed diets 0.8P-36S (Fig. 3 ). The decrease was seen between 100-120 min after the birds were first placed in the metabolic chamber (Kruskal-Wallis test, $\mathrm{P}<$ 0.05 for both periods). Hummingbirds fed diet $0.8 \mathrm{P}-36 \mathrm{~S}$ consumed on average $1.5 \mathrm{x}$ and $1.7 \mathrm{x}$ more $\mathrm{O}_{2}$ between $100-110$ and $110-120 \mathrm{~min}$ compared to birds fed diet $2.4 \mathrm{P}-12 \mathrm{~S}$. For hummingbirds fed both diets, there was also a significant decrease in $\mathrm{VO}_{2}$ consumption with time (Friedman's ANOVA test, $\mathrm{P}<0.01$ for diet $0.8 \mathrm{P}-36 \mathrm{~S} ; \mathrm{P}<0.001$ for $\operatorname{diet} 2.4 \mathrm{P}-12 \mathrm{~S}$ ).

To test whether there was a difference in mean total $\mathrm{VO}_{2}$ consumption for the whole 2-h experiment, values were compared between diets through one-way ANOVA (Table 3). There was no significant difference between the values (One-way ANOVA, $\mathrm{P}>0.05$ ). Mean value was $13.22 \mathrm{~mL} \mathrm{~g}^{-1} \mathrm{~h}^{-1}$ for birds fed diets $0.8 \mathrm{P}-36 \mathrm{~S}$ and $11.25 \mathrm{~mL} \mathrm{~g}^{-1} \mathrm{~h}^{-1}$ for birds fed diets $2.4 \mathrm{P}-12 \mathrm{~S}$.

There was a strong correlation coefficient between $\mathrm{VO}_{2}$ consumption and body temperature for hummingbirds during nonfeeding stage (Fig. 4; Spearman correlation analysis, $\mathrm{P}<0.001$ for diet $0.8 \mathrm{P}-36 \mathrm{~S} ; \mathrm{P}<0.001$ for diet $2.4 \mathrm{P}-12 \mathrm{~S}$ ). As body temperature goes down, oxygen consumption also decreases. Values of $\mathrm{VO}_{2}$ consumption and body temperature for birds which entered torpor show a decrease in $\mathrm{Tb}$ between 62-75\% and $\mathrm{VO}_{2}$ reach values as low as $0.51 \mathrm{~mL} \mathrm{~g}^{1} \mathrm{~h}^{-1}$ (Fig. 5).

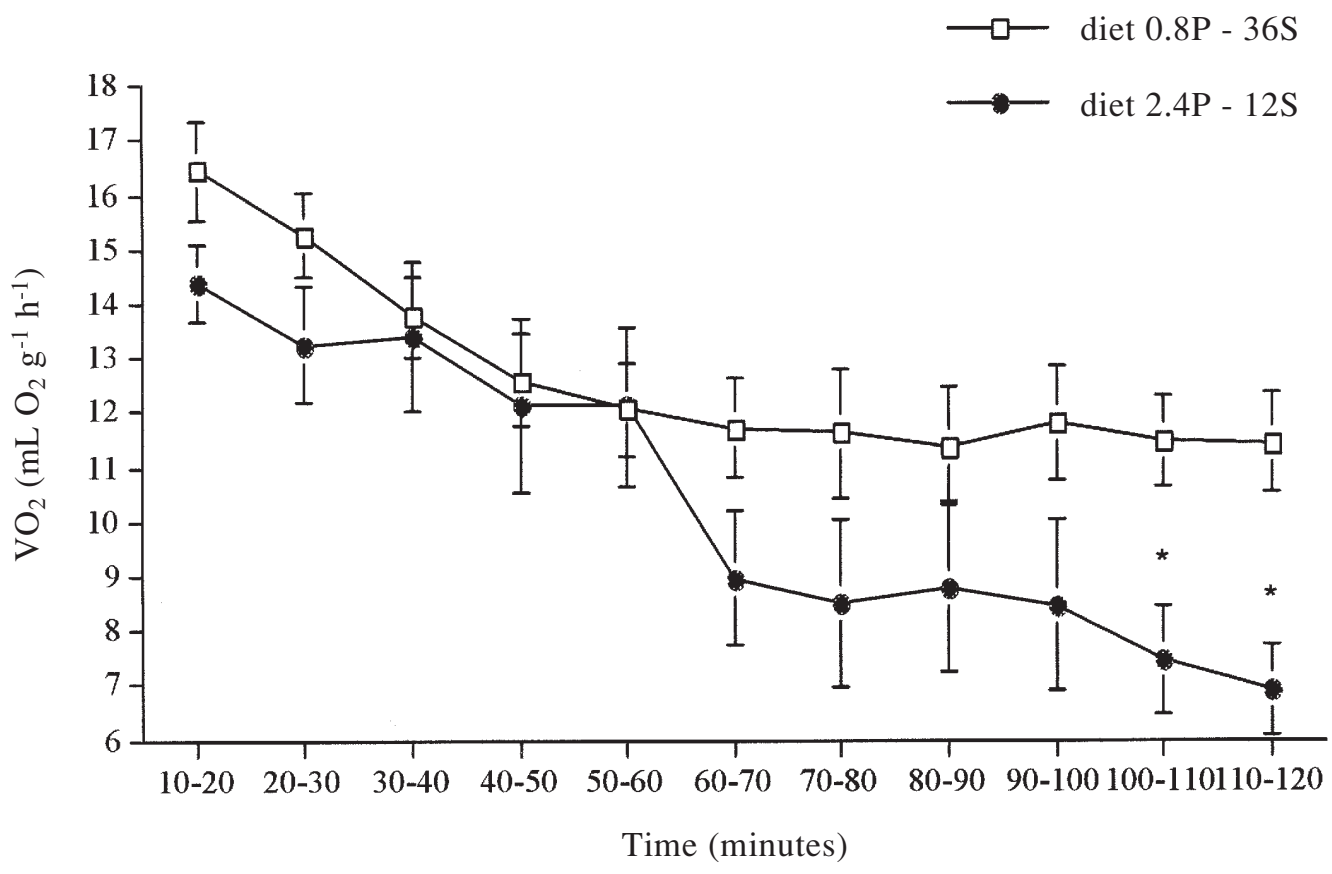

Fig. 3: Relationship between mean $\mathrm{VO}_{2}$ metabolic rate during non-feeding stage for hummingbirds fed two different diets. The consumption is shown at a 10 min time interval for birds which did not enter torpor. Diets as in Fig. 1. Means \pm SE are shown. Asterisks denote significant differences between diets within the same time period (Kruskal-Wallis test, $\mathrm{P}<0.05$ ).

Relación entre $\mathrm{VO}_{2}$ tasa metabólica media durante los estados de no alimentación en picaflores alimentándose dos dietas diferentes. Se muestra el consumo a intervalos de 10 min para aves que no entran en sopor. La dietas como en la Fig. 1. Medias \pm SE. Los asteriscos indican diferencias significativas entre dietas en el mismo período de tiempo (prueba de Kruskal-Wallis, $\mathrm{P}<0.05$ ) 


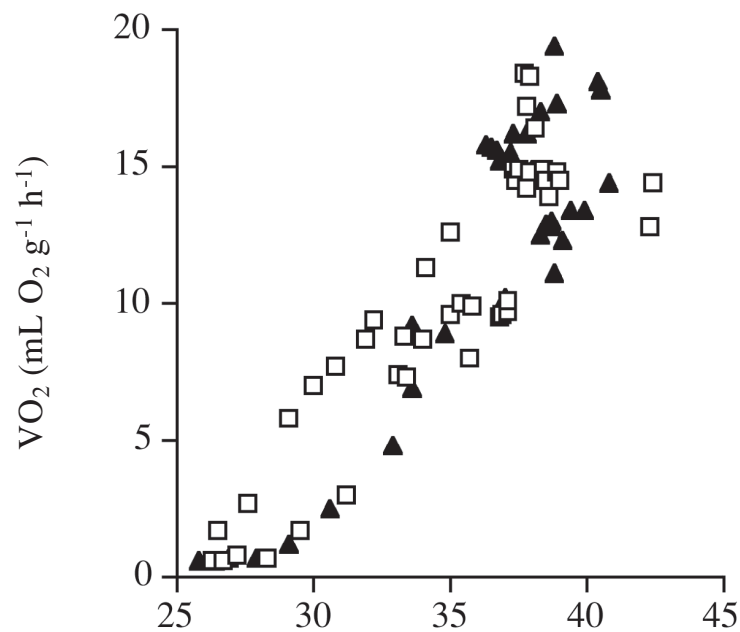

$\square \quad \operatorname{diet} 2.4 \mathrm{P}-12 \mathrm{~S}$
$\Delta \quad \operatorname{diet} 0.8 \mathrm{P}-36 \mathrm{~S}$

$\mathrm{Tb}\left({ }^{\circ} \mathrm{C}\right)$

Fig 4: Relationship between body temperature (Tb) and metabolic rate $\left(\mathrm{VO}_{2}\right)$ for hummingbirds fed two different diets during non-feeding stage. Each symbol represents individual values of $\mathrm{VO}_{2}$ consumption and $\mathrm{Tb}$ calculated every $10 \mathrm{~min}$ interval over the 2-h long experimental run. Diets used are outlined above.

Relación entre temperatura corporal $(\mathrm{Tb})$ y tasa metabólica $\left(\mathrm{VO}_{2}\right)$ en picaflores alimentándose de dos dietas diferentes durante el período de no alimentación. Cada símbolo representa valores individuales para $\mathrm{VO}_{2}$ y $\mathrm{Tb}$ calculados a intervalos de 10 min en un período de 2 h de duración. Las dietas como en la Fig. 1.

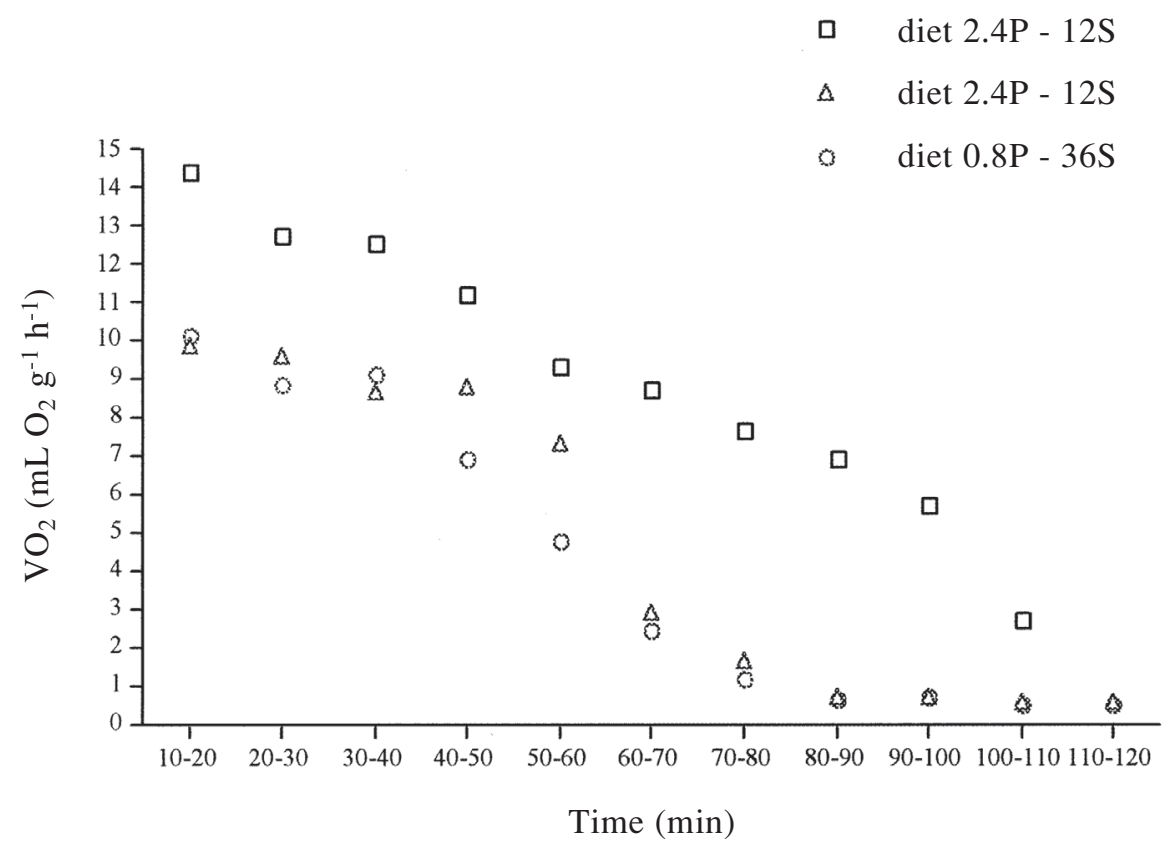

Fig 5: Relationship between metabolic rate $\left(\mathrm{VO}_{2}\right)$ and time after the birds were first inserted in the respirometer (measured at a $10 \mathrm{~min}$ interval) for three individual hummingbirds that entered torpor during a non-feeding stage. Two of the birds were fed diets containing $2.4 \%$ protein, $12 \%$ sucrose and one bird was fed diet containing $0.8 \%$ protein, $36 \%$ sucrose.

Relación entre la tasa metabólica $\left(\mathrm{VO}_{2}\right.$ y tiempo después que los picaflores fueron primero introducidos en el respirómetro (intervalo de $10 \mathrm{~min}$ ) para tres individuos que entraron en sopor durante el período de no alimentación. Dos aves se alimentaron con dietas que contenían $2,4 \%$ proteína, $12 \%$ sacarosa y un ave se alimentó con una dieta que contenía $0,8 \%$ proteína y $36 \%$ sacarosa. 


\section{TABLE 4}

Mean overall oxygen consumption $\left(\mathrm{VO}_{2}\right)$ for the whole non-feeding stage (2-h observation). There were no significant differences between diets for each of the observations (One-way ANOVA, $\mathrm{P}=0.142)$. Diets were composed of $0.8 \%$ protein $(\mathrm{P}), 36 \%$ sucrose $(\mathrm{S})$ and $2.4 \%$ protein $(\mathrm{P}), 12 \%$ sucrose $(\mathrm{S})$. Sample sizes $(\mathrm{n})$ are shown

Promedio de consumo de oxígeno $\left(\mathrm{VO}_{2}\right)$ durante todo el estado de no alimentación ( 2 h de onservación). No se observaron diferencias dsignificativas entre dietas para cada observación (ANOVA de una vía, $\mathrm{P}=0.142$ ). La composición dietaria fue: $0,8 \%$ proteína $(\mathrm{P}), 36 \%$ sacarosa (S) y $2,4 \%$ proteína $(\mathrm{P}), 12 \%$ sucrose $(\mathrm{S})$. Se indica el tamaño muestreal $(\mathrm{N})$.

\begin{tabular}{lcc}
\hline Diet & $\mathrm{VO}_{2}$ fasting & $\mathrm{n}$ \\
\hline $0.8 \mathrm{P}-36 \mathrm{~S}$ & $13.22 \pm 0.72$ & 8 \\
$2.4 \mathrm{P}-12 \mathrm{~S}$ & $11.25 \pm 0.90$ & 7 \\
\hline
\end{tabular}

\section{DISCUSSION}

Although in the protocols used in the present study we did not include experiments with balanced concentrations of protein and carbohydrate because of a lack of enough experimental animals for these additional experiments, we believe that the results which were obtained so far represent an important and interesting contribution to the understanding of how diet composition interferes on both feeding behavior and metabolic rate in Neotropical hummingbirds, an understudied group.

\section{Feeding behavior}

The results presented here show that periods of feeding on each of the diets could easily be distinguished as separate bouts or feeding events. Hummingbirds presented a high protein-low carbohydrate diets (2.4P-12S) ingested more diet, fed for longer (both around $1.7 \mathrm{x}$ larger) and increased the interval between feedings compared to hummingbirds fed diets $0.8 \mathrm{P}-36 \mathrm{~S}$. The results suggest, at least on a short-term basis, that feeding control mechanisms in hummingbirds are easily distinguished when they are presented to diets with contrasting amounts of protein and carbohydrate. Moreover, assuming that hummingbirds are usually energy-limited and spend most of their foraging time searching for nectar, it would be expected that hummingbirds could potentially show an increased tendency to feed for longer and in larger quantities on high protein-low sugar diets, to account for the low energy present on this diet.

On the other hand, we would expect feeding frequency to increase (i.e., interval between feedings to decrease) if birds were regulating the intake of low amounts of sugar and energy under diet $2.4 \mathrm{P}-12 \mathrm{~S}$, maximizing in this way their sugar intake. The decrease in feeding frequency suggests that some physiological constraint was probably delaying the birds' initiation of next feeding. Particularly, birds on these diets ate $1.8 \mathrm{x}$ less carbohydrate compared with hummingbirds on the other diet. In contrast, they ate $5 \mathrm{x}$ more protein than hummingbirds on diet $0.8 \mathrm{P}-36 \mathrm{~S}$. In addition, the difference in dietary content for both protein and carbohydrate between the two experimental diets was the same $(3 x)$, suggesting that carbohydrate regulation was not complete within the experimental time presented here, while for protein, the difference eaten became even more extreme than dietary content difference. Based on this reasoning, the results suggest that metabolic feedbacks related to an excess of protein ingestion on hummingbirds fed diet $2.4 \mathrm{P}-12 \mathrm{~S}$ was preventing further carbohydrate ingestion, resulting in this way on a decrease in feeding frequency (see discussion on dietary imbalance concepts in Raubenheimer 1992).

Metabolic feedback during regulation of food intake is well known in other groups of animals e.g., vertebrates (Campfield \& Smith 1990, Le Magnen 1992) and insects (see Abisgold \& Simpson 1987, Zanotto et al. 1996). In the case reported here, ingesting more of the $2.4 \mathrm{P}-12 \mathrm{~S}$ diet to gain limiting sugar, the hummingbirds were also ingesting excess protein and metabolic feedbacks related to excess protein ingestion could be curtailing further sugar regulation and as a consequence these feedbacks could be delaying next feeding. Interestingly, phytophagous insects, for example, are nitrogen limited and dietary experiments on a short-term basis show a strong behavioral and physiological regulation for protein when diets are presented in unbalanced proportions or diluted in relation to this component (see review by Simpson \& Raubenheimer 1993). Using a similar reasoning, hummingbirds, which occupy the 
same niche as some insects, are usually energylimited and show a lower protein requirement when compared to other birds (Brice \& Grau 1991). Therefore, we would expect a stronger regulatory control for low amounts of sugar in their diet. However, low sugar diet in conjunction with elevated levels of protein as seen here seem to affect the number of feeding bouts in these birds in a way as to lengthen their feeding interval, probably to permit them metabolize excess protein ingested. LopezCalleja et al. (2003) also discussed nitrogen digestibility in hummingbirds and saw that it declined in hummingbirds fed $11.1 \%$ nitrogen diet, suggesting that these birds are unable to digest diets with high amounts of protein, strengthening our point of a decreased feeding frequency on a high protein-low carbohydrate diets, because of a protein overload.

The only work addressing the interaction between sugar and protein on hummingbird's feeding is that of Hainsworth \& Wolf (1976). In this work, hummingbirds did not show any behavioral preference or discrimination for amino acids paired with sugars. Interestingly, Wolf \& Hainsworth (1977) found that hummingbirds feeding in the laboratory had distinct feeding bouts that averaged less than 10s. Suarez et al. (1990) similarly saw that almost all hover feeding bouts lasted less than $10 \mathrm{~s}$. These results are in agreement with values found here for both diets.

An alternative hypothesis to explain decreased feeding frequency on diets $2.4 \mathrm{P}-12 \mathrm{~S}$ could be associated with the rate of gut emptying and the volume of diet ingested (Beuchat et al. 1990, López Calleja et al. 1997). Wollf and Hainsworth (1977) found that hummingbirds fed diets with different sugar concentrations and different rates of extraction (accomplished through an increase in the flower 'corolla' length), did not vary the volume intake for any of the dietary concentrations used, but the hummingbirds fed for longer when rate of intake was decreased. Indeed, Wolf \& Hainsworth (1977) found that hummingbirds did not fill completely their crop, and they hypothesized that this could be related to the cost/benefit ratio of the added weight a larger storage of nectar in the crop could incur to the hummingbirds. A similar mechanism could explain here why hummingbirds fed less frequently on diets
$2.4 \mathrm{P}-12 \mathrm{~S}$, i.e., to compensate for the larger volume of diet eaten and the associated water load (Beuchat et al. 1990).

In the field, rufous hummingbirds usually feed 14-18 times per hour and have a mean meal size of $70 \mu \mathrm{L}$ (Hixon et al 1983). Assuming that hummingbirds in the present study ingested approximately the same amount of liquid diet every time they fed, our calculations resulted in an average meal size of $71 \mu \mathrm{L}$ for birds fed diet $0.8 \mathrm{P}-36 \mathrm{~S}$, and $139 \mu \mathrm{L}$ for those fed diet $2.4 \mathrm{P}-$ 12S. Diamond et al. (1986) and Karasov et al. (1986) estimated $4.1 \mathrm{~min}$ as half-time for clearing the crop of $100 \mu \mathrm{L}$ of ingested diet. Here we found that hummingbirds on diets 2.4P$12 \mathrm{~S}$ started to eat again 3.9 min later, within the range found by Diamond et al. (1986), although their meal size was larger. However, those fed diet $0.8 \mathrm{P}-36 \mathrm{~S}$ started to feed earlier (average 1.9 $\mathrm{min}$ ) on a lower meal size. These results suggest, in contrast to metabolic feedbacks discussed above, the presence of a digestive constraint related to crop emptying time, at least under diet $2.4 \mathrm{P}-12 \mathrm{~S}$, resulting in a longer feeding frequency in these birds as a consequence of a supposed slower processing rate (Diamond et al. 1986).

Although this kind of discussion can throw some light on general feeding trends, foraging strategies among hummingbird species and prevailing ecological conditions are known to be under a variety of evolutionary constraints. For example, Beuchat et al. (1979) saw that two hummingbirds species exposed to low ambient temperature adopted different foraging strategies. One bird increased meal size and the other species increased its feeding frequency to account for the higher energy expenditure. Hainsworth et al. (1981) also found that two species of hummingbirds regulated food intake differently when food deprived.

Eugenes increased feeding frequency while Lampornis increased the size of the meal. Fernandez et al. (2002) also observed that hummingbirds adopted different foraging behavior depending on the need to thermoregulate or to get high quality food. When thermoregulatory costs were high, Sephanoides preferred to conserve energy even though they could feed on a high quality food. Therefore, it is not really known the specific ecological conditions or the evolutionary constraints which allow hummingbirds to alter 
their feeding strategies during increased energy expenditure or, as the case here, during exposure to a dietary imbalance. It shows, however, behavioral flexibility during energy regulation by these birds.

\section{Respirometry}

Feeding stage. There was a larger increase in metabolic rate for hummingbirds fed diets $0.8 \mathrm{P}-36 \mathrm{~S}$ compared to birds fed the high protein, low carbohydrate diet, where levels stabilized at the same initial values as feeding progressed and ended. The thermogenic effect of carbohydrate overfeeding is known in vertebrates (e.g., Astrup et al. 1986). These higher respiratory rates are usually related to digestion and assimilation of a supposed excess carbohydrate. Sugar assimilation is known to be costly for hummingbirds because they have the highest intestine transport rates of sucrose among vertebrates (Diamond et al. 1986, Karasov et al. 1986), a process known to use great amounts of energy as ATP, with active transport accounting for virtually all of the glucose absorption (Karasov et al. 1986).

Moreover, it was found that intestinal sucrose hydrolysis rates in hummingbirds are near maximal and may impose limits to sugar assimilation in these birds (McWhorter et al. 2000).

Interestingly, the amount of $\mathrm{O}_{2}$ consumption theoretically calculated in relation to amounts eaten of protein and carbohydrate for each of the diets (Schmidt-Nielsen 1996), show values of around $1.5 \mathrm{x}$ more $\mathrm{O}_{2}$ production for hummingbirds fed diet $0.8 \mathrm{P}-36 \mathrm{~S}$ compared to those fed diet 2.4P-12S. Here the results show $1.4 \mathrm{x}$ more $\mathrm{O}_{2}$ consumption, very close to the theoretical value.

Non-feeding stage. There were no major differences in respiratory parameters between hummingbirds fed the different diets. The only striking difference was a steeper decrease in $\mathrm{VO}_{2}$ consumption for fasted hummingbirds previously fed diet $2.4 \mathrm{P}-12 \mathrm{~S}$ compared to the other diet. This decrease was more evident 100 min after birds were placed in the respirometer. Birds fed these diets were theoretically sugar and energy deprived, based on behavioral data. A larger decline in $\mathrm{VO}_{2}$ consumption could be a consequence of a faster metabolic depression in these birds.
From a total of seven hummingbirds tested on diet $2.4 \mathrm{P}-12 \mathrm{~S}, 2$ entered torpor and one out of eight fed diet $0.8 \mathrm{P}-36 \mathrm{~S}$ also entered torpor. The torpor state was based on a 60-90\% decrease in $\mathrm{VO}_{2}$ consumption and a body temperature $(\mathrm{Tb})$ of $25-26{ }^{\circ} \mathrm{C}$, around $4{ }^{\circ} \mathrm{C}$ above ambient temperature $\left(\mathrm{Ta}=21{ }^{\circ} \mathrm{C}\right)$ (Withers 1977, Kruger et al. 1982, Hiebert 1993). It remains an open issue whether birds on these diets were energy limited, therefore being more susceptible to entry into torpor. Hiebert et al (2000) saw that captive rufous hummingbirds exposed to diluted nectar showed increased torpor duration and frequency. Interestingly, Abe et al. (1995) studied torpor in different species of hummingbirds, which also included Melanotrochilus fuscus. Unlike the other hummingbird species, which entered torpor many times during the night, Melanotrochilus had only one period of torpor during the night. Additionally, they would enter torpor only when fasted for longer than $100 \mathrm{~min}$. Therefore, because of a larger body mass, Melanotrochilus seem to have a decreased propensity to enter torpor. There was a strong positive correlation between $\mathrm{Tb}$ and $\mathrm{VO}_{2}$ consumption for fasted hummingbirds, although these birds did not enter into torpor within the 2-h experimental period. Powers (1991) reported a decrease in $\mathrm{VO}_{2}$ consumption in non-torpid hummingbirds after the first hour of the night. His values stabilized to levels close to what we found here after a 2-h fast. However, we do not know whether the decrease in metabolic rate with time seen here was related to a longer time to reach a postabsorptive state (Powers 1991) or whether it was an artifact of the experimental conditions which could be potentially inducing torpor in the birds sooner or later (Morris et al. 1994).

\section{CONCLUSIONS}

The findings presented here suggest that hummingbirds were able to regulate behaviorally when fed diets with contrasting amounts of dietary protein and carbohydrate through both an increase in meal size and a change in feeding frequency. Physiological regulation was seen through an increase in metabolic rate for low protein-high sugar diets, 
suggesting that it could possibly be related to high sucrose assimilation rates on these diets (Diamond et al. 1986). The results also suggest that hummingbirds show a high degree of physiological plasticity when presented to diets with contrasting amounts of protein and carbohydrate. This response could probably be related to differences in food availability between seasons or even fine-tuned metabolic machinery able to operate at the edge, already well known for hummingbirds in general (see recent work by Fernandez et al. 2002, LópezCalleja \& Bozinovic 2003).

Interestingly, most studies on hummingbirds have been performed using temperate species from North America. Neotropical hummingbirds, on the other hand, do not undergo long migratory flights as temperate species and therefore energy storage in the form of lipids is not as crucial for survival in these Neotropical species. It is potentially interesting to compare the response of temperate species to a dietary imbalance, particularly low carbohydrate diets, and see how the hummingbirds deal with sugar deficit and the associated energy storage under these conditions. Although the present work did not separate any specific mechanism that could explain the interactive effects of dietary protein and carbohydrate, it could represent, however, a starting point to further untangle the machinery of energetic savings in these birds.

\section{ACKNOWLEDGMENTS}

This work was supported by CNPq PostDoctoral Fellowship and by FAPESP grant \# 96/08949-2 to FPZ. We thank Dr. Raul K. Suarez, Dr. David Goldstein and Dr. Steve J. Simpson for useful comments during manuscript preparation. This manuscript honors Dr. Mario Rosenmann.

\section{LITERATURE CITED}

ABE AS, C BECH, JF STEFFENSEN, M BERGER \& JEPW BICUDO (1995) Torpor e energética em beija-flores do Sudeste brasileiro. Boletim do Museu de Biologia Mello Leitão (Brazil) 2: 3-13

ABISGOLD JD \& SJ SIMPSON (1987) The physiology of compensation by locusts for changes in dietary protein. Journal of Experimental Biology 129: 329-346
ASTRUP A, J BALOW, NJ CHRISTENSEN, J MADSEN \& F QUAADE (1986) Facultative thermogenesis induced by carbohydrate: a skeletal muscle component mediated by epinephrine. American Journal of Physiology 250: E226-E229.

BAKER HG (1975) Sugar concentrations in nectars from hummingbirds flowers. Biotropica 7: 37-41.

BAKER HG \& I BAKER (1973) Amino-acids in nectar and their evolutionary significance. Nature 241: 543-545.

BARTHOLOMEW GA, D VLECK \& CM VLECK (1981) Instantaneous measurement of oxygen consumption during pre-flight warm up and post-flight cooling in sphingid and saturniid moths. Journal of Experimental Biology 90: 17-32.

BEUCHAT CA, SB CHAPLIN \& ML MORTON (1979) Ambient temperature and the daily energetics of two species of hummingbirds, Calypte anna and Selasphorus rufus. Physiological Zoology 53: 280295.

BEUCHAT CA, WA CALDER III \& EJ BRAUN (1990) The integration of osmoregulation and energy balance in hummingbirds. Physiological Zoology 63: 1059-1081.

BRICE AT (1992) The essentiality of nectar and arthropods in the diet of the Anna's hummingbird (Calypte anna). Comparative Biochemistry and Physiology A 101A: 151-155.

BRICE AT \& CR GRAU (1991) Protein requirements of Costa's hummingbird Calypte costae. Physiological Zoology 64: 611-626.

CAMPFIELD LA \& FJ SMITH (1990) Systemic factors in the control of food intake: evidence for patterns as signals. In: Stricker EM (ed) Handbook of behavioral neurobiology: 183-205. Plenum Press, New York, New York, USA. 600 pp.

DE BENEDICTS PA, FB GILL, FR HAINSWORTH, GH PYKE \& LL WOLF (1978) Optimal meal size in hummingbirds. American Naturalist 112: 301-316.

DIAMOND JM, WH KARASOV, D PHAN \& FL CARPENTER (1986) Digestive physiology is a determinant of foraging bout frequency in hummingbirds. Nature 320: 62-63.

DREISIG H (1997) Why do some nectar foragers perch and others hover while probing flowers? Evolutionary Ecology 11: 543-555.

FERNÁNDEZ MJ, MV LÓPEZ-CALLEJA \& F BOZINOVIC (2002) Interplay between the energetics of foraging and thermoregulatory costs in the hummingbird Sephanoides sephaniodes. Journal of Zoology, London 258: 319-326.

GOTTSBERGER G, J SCHRAUWEN \& HF LINSKENS (1984) Amino acids and sugar in nectar, and their putative evolutionary significance. Plant Systematics and Evolution 145: 55-77.

HAILEY A, RL CHIDAVAENZI \& JP LOVERIDGE (1998) Diet mixing in the omnivorous tortoise Kinixys spekii. Functional Ecology 12: 373-385.

HAINSWORTH FR \& LL WOLF (1976) Nectar characteristics and food selection by hummingbirds. Oecologia 25: 101-113.

HAINSWORTH FR, MF TARDIFF \& LL WOLF (1981) Proportional control for daily energy regulation in hummingbirds. Physiological Zoology 54: 452462.

HAINSWORTH FR \& LL WOLF (1983) Models and evidence for feeding control of energy. American Zoologist 23: 261-272.

HIEBERT S (1993) Seasonal changes in body mass and use of torpor in a migratory hummingbird. Auk 110 : 787-797. 
HIEBERT SM, KG SALVANTE, M RAMENOFSKY \& JC WINGFIELD (2000) Corticosterone and nocturnal torpor in the rufous hummingbird (Selasphorus rufus). General and Comparative Endocrinology 120: 220-34.

HIEBERT SM \& WA CALDER III (1983) Sodium, potassium, and chloride in floral nectars: energyfree contributions to refractive index and salt balance. Ecology 64: 399-402.

HIXON MA, FL CARPENTER \& DC PATON (1983) Territory area, flower density, and time budgeting in hummingbirds: an experimental and theoretical analysis. American Naturalist 122: 336-391.

HOUSTON AI \& DC KRAKAUER (1993) Hummingbirds as net rate maximisers. Oecologia 94: 135-138.

JOHANSEN K, M BERGER, A RUSCHI, PJ ALMEIDA \& JEPW BICUDO (1987) Respiratory properties of blood and myoglobin in hummingbirds. Physiological Zoology 60: 269-278.

KARASOV WH, D PHAN, JM DIAMOND \& FL CARPENTER (1986) Food passage and intestinal nutrient absorption in hummingbirds. Auk 103: 453-464.

KINGSOLVER JG \& TL DANIEL (1983) Mechanical determinants of nectar feeding strategy in hummingbirds: energetics, tongue morphology, and licking behaviour. Oecologia 60: 214-226.

KRUGER K, R PRINZINGER, \& KL SCHUCHMANN (1982) Torpor and metabolism in hummingbirds. Comparative Biochemistry and Physiology 73: 679689.

LE MAGNEN J (1992) Neurobiology of feeding and nutrition. Academic Press, San Diego, California, USA. 385 pp.

LÓPEZ-CALLEJA MV \& F BOZINOVIC (2003) Dynamic energy and time budget in hummingbirds: a study in Sephanoides sephaniodes. Comparative Biochemistry \& Physiology 134: 283-295.

LÓPEZ-CALLEJA MV, F BOZINOVIC \& C MARTÍNEZ DEL RÍO (1997) Effect of sugar concentration on hummingbird feeding and energy use. Comparative Biochemistry and Physiology A 119: 1291-1299.

LÓPEZ-CALLEJA MV, MJ FERNÁNDEZ, F BOZINOVIC (2003) The integration of energy and nitrogen balance in the hummingbird Sephanoides sephaniodes. Journal of Experimental Biology 206: 3349-3359.

MARTÍNEZ DEL RÍO C (1990) Sugar preferences in hummingbirds: the influence of subtle chemical differences on food choice. Condor 92: 1022-1030.

MARTÍNEZ DEL RÍO C, HG BAKER \& I BAKER (1992) Ecological and evolutionary implications of digestive processes: bird preferences and the sugar constituents of floral nectar and fruit pulp. Experientia 48: 544-551.

MCWHORTER TJ \& C MARTÍNEZ DEL RÍO (2000) Does gut function limit hummingbird food intake? Physiological and Biochemical Zoology 73: 313-24.

MORRIS S, AL CURTIN \& MB THOMPSON (1994) Heterothermy, torpor, respiratory gas exchange, water balance and the effect of feeding in Gould's long-eared bat Nyctophilus gouldi. Journal of Experimental Biology 197: 309-335.

POWERS DR (1991) Diurnal variation in mass, metabolic rate, and respiratory quotient in Anna's and Costa's hummingbirds. Physiological Zoology 64: 850-870.

RAUBENHEIMER D (1992) Tannic acid, protein, and digestible carbohydrate: dietary imbalance and nutritional compensation in locusts. Ecology 73: 1012-1027.

ROBERTS WM (1996) Hummingbirds' nectar concentration preferences at low volume: the importance of time scale. Animal Behavior 52: 361370.

SCHMIDT-NIELSEN K (1996) Fisiologia animal: adaptação e meio ambiente. Livraria Santos Editora, São Paulo, Brazil. 602 pp.

SIMPSON SJ (1982) Patterns in feeding: a behavioural analysis using Locusta migratoria nymphs. Physiological Entomology 7: 325-336.

SIMPSON SJ \& D RAUBENHEIMER (1993) A multilevel analysis of feeding behaviour: the geometry of nutritional decisions. Philosophical Transactions of the Royal Society of London 343: 395-403.

SNOW DW \& BK SNOW (1986) Feeding ecology of hummingbirds in the Serra do Mar, southeastern Brazil. El Hornero (Argentina) 12: 286-296.

SOKAL RR \& FJ ROHLF (1981) Biometry. Second edition. W. H. Freeman and Company, New York, New York, USA. 887 pp.

STILES FG (1976) Taste preferences, color preferences, and flower choice in hummingbirds. Condor 78: 1026.

SUÁREZ RK, GS BROWN \& PW HOCHACHKA (1986) Metabolic sources of energy for hummingbird flight. American Journal of Physiology 251: R537R542.

SUÁREZ RK, RW BROWNSEY, W VOGL, GS BROWN \& PW HOCHACHKA (1988) Biosynthetic capacity of hummingbird liver. American Journal of Physiology 255: R-699-R702.

SUÁREZ RK, JRB LIGHTON, CD MOYES, GS BROWN, CL GASS \& PW HOCHACHKA (1990) Fuel selection in rufous hummingbirds: ecological implications of metabolic biochemistry. Proceedings of the National Academy of Sciences USA 87: 9207-9210.

SUÁREZ RK, JRB LIGHTON, GS BROWN \& O MATHIEU-COSTELLO (1991). Mitochondrial respiration in hummingbird flight muscles. Proceedings of the National Academy of Sciences USA 88: 4870-4873.

SUÁREZ RK \& CD MOYES (1992) Mitochondrial respiration in locust flight muscles. Journal of Experimental Zoology 263: 351-355.

WELLS DJ (1993). Ecological correlates of hovering flight of hummingbirds. Journal of Experimental Biology 178: 59-70.

WITHERS PC (1977) Respiration, metabolism, and heat exchange of euthermic and torpid poorwills and hummingbirds. Physiological Review 57: 43-52.

WOLF LL \& FR HAINSWORTH (1977) Temporal patterning of feeding by hummingbirds. Animal Behaviour 25: 976-989.

ZANOTTO FP, D RAUBENHEIMER \& SJ SIMPSON (1996) Haemolymph amino acid and sugar in locusts fed nutritionally unbalanced diets. Journal of Comparative Physiology 166: 223-229. 